\title{
Silver staining (Campbell-Switzer) of neuronal a-synuclein assemblies induced by multiple system atrophy and Parkinson's disease brain extracts in transgenic mice
}

Isabelle Lavenir', Daniela Passarella', Masami Masuda-Suzukake', Annabelle Curry', Janice L. Holton², Bernardino Ghetti ${ }^{3}$ and Michel Goedert ${ }^{1 *}$

\begin{abstract}
Synucleinopathies [Parkinson's disease (PD), dementia with Lewy bodies (DLB) and multiple system atrophy (MSA)] share filamentous a-synuclein assemblies in nerve cells and glial cells. We compared the abilities of brain extracts from MSA and PD patients to induce neuronal a-synuclein assembly and neurodegeneration following intracerebral injection in heterozygous mice transgenic for human mutant A53T a-synuclein. MSA extracts were more potent than PD extracts in inducing a-synuclein assembly and in causing neurodegeneration. MSA assemblies were Campbell-Switzer- and Gallyas-silver-positive, whereas PD assemblies were only Campbell-Switzer-positive, in confirmation of previous findings. However, induced a-synuclein inclusions were invariably Campbell-Switzerpositive and Gallyas-negative, irrespective of whether MSA or PD brain extracts were injected. The a-synuclein inclusions of non-injected homozygous mice transgenic for A53T a-synuclein were also Campbell-Switzer-positive and Gallyas-negative. These findings demonstrate that transgene expression and its intracellular environment dominated over the silver staining properties of the conformers of assembled a-synuclein.
\end{abstract}

Keywords: a-Synuclein, Multiple system atrophy, Parkinson's disease, Seeding, Silver staining, Transgenic

\section{Introduction}

The ordered assembly of $\alpha$-synuclein into abnormal filaments defines a group of neurodegenerative diseases called synucleinopathies [18]. $\alpha$-Synuclein was linked to Parkinson's disease (PD), when a dominantly inherited missense mutation (A53T) in SNCA, the $\alpha$-synuclein gene, was found to cause a familial form of PD [39]. Subsequently, genome-wide association studies also identified $\alpha$-synuclein as a significant risk factor for idiopathic PD [32]. $\alpha$-Synuclein is the major component of Lewy bodies and Lewy neurites, the intraneuronal filamentous assemblies found in all patients with PD, with or without dementia, and in patients with dementia with Lewy bodies (DLB) [44, 45]. $\alpha$-Synuclein not only accumulates in Lewy pathology, but it can also template its assembly. Injection of misfolded $\alpha$-synuclein induces

\footnotetext{
* Correspondence: mg@mrc-Imb.cam.ac.uk

${ }^{1}$ MRC Laboratory of Molecular Biology, Cambridge CB2 0QH, UK Full list of author information is available at the end of the article
}

assembly of endogenous protein into phosphorylated assemblies that resemble Lewy bodies [26, 31]. Neurons bearing Lewy bodies eventually die $[19,33]$.

Filamentous inclusions of multiple system atrophy (MSA) are also made of $\alpha$-synuclein [43, 47, 51]. MSA is more aggressive than PD and DLB, with an interval between diagnosis and death of approximately 9 years [11]. The defining lesion of MSA is the presence of $\alpha$-synuclein inclusions in oligodendrocytes, the majority of which are in the form of cytoplasmic inclusions [glial cytoplasmic inclusions (GCIs) or Papp-Lantos inclusions [34, 35]]. Smaller numbers of filamentous $\alpha$-synuclein inclusions are also present in the nuclei, cytoplasm and processes of some neurons [8]. Inclusions comprise $\alpha$ synuclein phosphorylated at S129 $[1,13]$.

Much previous work on seeded aggregation used M83 mice, which are transgenic for human mutant A53T $\alpha$ synuclein, under the control of the prion protein promoter

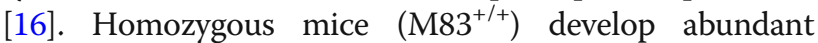


neuronal inclusions made of filamentous pS129 $\alpha$ synuclein and neurodegeneration when aged 8-16

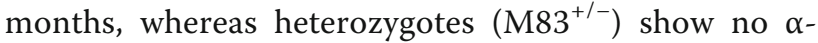
synuclein inclusions or neurodegeneration until 20 months of age. Inclusions are most abundant throughout spinal cord and hindbrain, followed by midbrain, thalamus and hypothalamus.

Experimental studies established that the intracellular milieu of oligodendrocytes is essential for the formation of GCI-specific conformers of assembled $\alpha$-synuclein [33]. Previous investigations using mouse models of seeded pathology through intracerebral injections with brain samples from patients with either PD or MSA showed that MSA extracts were capable of inducing neuronal $\alpha$ synuclein pathology in transgenic mice $[40,52]$. Thus, homogenates from the brains of patients with MSA induced the formation of abundant $\alpha$-synuclein inclusions and neurodegeneration characterized by motor symptoms in

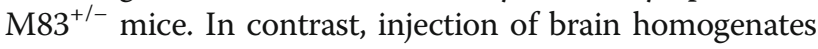
from the brains of PD patients failed to induce the formation of either $\alpha$-synuclein inclusions or neurodegeneration. These findings lent support to the view that different conformers of assembled $\alpha$-synuclein are typical of PD and MSA.

Although the filamentous inclusions of MSA and PD are made of modified, assembled $\alpha$-synuclein, they can be distinguished using silver staining, consistent with the presence of distinct conformers [35, 49]. Thus, GCIs and neuronal inclusions exhibit argyrophilia with both Campbell-Switzer and Gallyas, whereas Lewy pathology stains with Campbell-Switzer, but not Gallyas.

We injected brain homogenates from 7 MSA and 5 PD cases, all neuropathologically confirmed, into the hippocampus and overlying cerebral cortex of $\mathrm{M} 83^{+/-}$mice. Thirty mice injected with MSA brain extracts developed abundant neuronal $\alpha$-synuclein inclusions and neurodegeneration, with an incubation time of $167 \pm 17$ days. The same was true of 7 of 17 mice injected with PD extracts (incubation time of $286 \pm 62$ days). By 18 months of age, 5 additional mice had developed $\alpha$-synuclein inclusions, in the absence of neurodegeneration.

Inclusions were positive with Campbell-Switzer and negative with Gallyas silver, irrespective of whether MSA or PD extracts were injected. The same was true of assembled recombinant $\alpha$-synuclein, which induced the formation of abundant $\alpha$-synuclein inclusions and caused neurodegeneration (incubation time of $145 \pm 10$ days). $\alpha$ Synuclein inclusions of non-injected ${\mathrm{M} 83^{+/+}}$mice were also Campbell-Switzer-positive and Gallyas-negative.

\section{Materials and methods}

\section{Transgenic mice}

The M83 transgenic mouse line, which expresses human mutant A53T $\alpha$-synuclein under the control of the mouse prion protein promoter [16], was purchased from the Jackson Laboratory (stock number 004479). Mice heterozygous and homozygous for the transgene were used. All experiments were carried out in compliance with the Animals (Scientifc Procedures) Act of 1986 and were approved by the local Animal Welfare and Ethical Review Board.

\section{Human brain tissues}

Frozen brain tissues from neuropathologically confirmed cases of MSA and PD were obtained from the Queen Square Brain Bank for Neurological Disorders (London, UK) and the tissue collection at Indiana University (Indianapolis, USA). Tissues were homogenised in phosphate-buffered saline (PBS) $(200 \mathrm{mg} / \mathrm{ml})$, sonicated (Misonix: output 2 for $5 \times 0.9 \mathrm{~s}$ ) and centrifuged in the cold at $3000 \mathrm{~g}$ for $5 \mathrm{~min}$. Supernatants were aliquoted, snap frozen and stored at $-80^{\circ} \mathrm{C}$ until use.

\section{Recombinant human a-synuclein}

Full-length human $\alpha$-synuclein was expressed and purified, as described [23, 53]. It was assembled into filaments by incubating $400 \mu \mathrm{M}$ at $37^{\circ} \mathrm{C}$ for $48 \mathrm{~h}$ with constant agitation at $450 \mathrm{rpm}$.

\section{Intracerebral injection}

Three-month-old heterozygous M83 mice were anaesthetised with isoflurane and injected unilaterally with $5 \mu \mathrm{l}$ human brain extract or $5 \mu \mathrm{l}$ assembled recombinant human $\alpha$-synuclein $(400 \mu \mathrm{M})$, as described for tau assemblies [6]; $2.5 \mu \mathrm{l}$ were injected into the right hippocampus $(\mathrm{A} / \mathrm{P},-2.5 \mathrm{~mm} ; \mathrm{M} / \mathrm{L},+2.0 \mathrm{~mm} ; \mathrm{D} / \mathrm{V},-2.0 \mathrm{~mm})$ and $2.5 \mu \mathrm{l}$ into the overlying cerebral cortex $(\mathrm{A} / \mathrm{P},-2.5$ $\mathrm{mm} ; \mathrm{M} / \mathrm{L},+2.0 \mathrm{~mm} ; \mathrm{D} / \mathrm{V},-1.0 \mathrm{~mm})$ at a speed of $1.25 \mu \mathrm{l} / \mathrm{min}$. Following injection, the needle was kept in place for another $3 \mathrm{~min}$. Mice were given analgesia (Rimadyl, $4 \mathrm{mg} / \mathrm{kg}$ ) prior to surgery and were placed on a heat mat; their body temperatures were monitored throughout surgery and they were placed in a heat cabinet after surgery to aid recovery.

\section{Survival}

Following stereotaxic brain injections, mice were monitored weekly for signs of motor impairment. When they reached hind limb paralysis, they were humanely killed and their brains and spinal cords collected. KaplanMeier survival curves were produced using Graphpad Prism 7.

\section{Dot blotting}

The levels of $\alpha$-synuclein phosphorylated at S129 were determined by dot blotting (Minifold I Spot-Blot System, GE Healthcare), using human brain samples diluted 1: 1000, and run in quadruplicate. Dried nitrocellulose 
Table 1 Motor impairment of heterozygous mice transgenic for human mutant A53T a-synuclein following intracerebral injection of brain extracts from multiple system atrophy (MSA)

\begin{tabular}{llllll}
\hline Human brain extract & Age at death & Mice injected & Mice with motor impairment & Survival (days) & SD \\
\hline (1) MSA-P & 68 & 10 & 10 & 168 & 181 \\
(2) MSA-P & 75 & 2 & 2 & 166 & 12 \\
(3) MSA-P & 82 & 3 & 3 & 4 & 166 \\
(4) MSA-P & 65 & 4 & 4 & 168 & 28 \\
(5) MSA-P & 83 & 4 & 3 & 174 & 19 \\
(6) MSA-C & 69 & 3 & 4 & 152 & 23 \\
(7) MSA-C & 60 & 4 & &
\end{tabular}

membranes (Amersham) were blocked, incubated with a polyclonal pS129 $\alpha$-synuclein antibody (ab18467, Abcam, 1:5000) for $3 \mathrm{~h}$ at room temperature, followed by secondary antibody (1:4000) for $1 \mathrm{~h}$. Chemiluminescence and ImageJ were used to quantify the signal. Phosphorylation of purified recombinant human $\alpha$-synuclein at S129 using casein kinase-2 (New England Biolabs) was done as described [42]. Serial dilutions (0.5-3.5 ng) were used as standard. The linear parts of the standard curves were used to measure the concentrations of pS129 $\alpha$-synuclein.

\section{Immunohistochemistry and silver staining}

Mice were terminally anaesthetised and transcardially perfused with $20 \mathrm{ml}$ cold PBS, followed by $20 \mathrm{ml} 4 \%$ paraformaldehyde in 0.1 M phosphate buffer. Brains and spinal cords were dissected and postfixed overnight. Fixed tissues were paraffin-embedded and $8 \mu \mathrm{m}$ sections cut. Following deparaffinisation, the sections were incubated in blocking buffer $[\mathrm{PBS}+0.1 \%$ Triton X-100 $(\mathrm{PBST})+10 \%$ foetal calf serum] for $15 \mathrm{~min}$ at room temperature, followed by an overnight incubation with primary antibody specific for pS129 $\alpha$-synuclein (ab51253, Abcam, 1:5000 dilution) in blocking buffer. After three rinses with PBST, the sections were incubated with biotin-conjugated secondary anti-rabbit antibody (1:200 dilution) for $1 \mathrm{~h}$ at room temperature. The antigen was visualised with the Vector VIP substrate kit (Vector Laboratories). Fixed, deparaffinised tissue sections were stained using Campbell-Switzer [4, 5] or Gallyas [6, 15] silver, as described. All sections were counterstained with haematoxylin and coverslipped using Pertex mounting medium.

\section{Results}

We homogenised and sonicated cerebellum (7 cases of MSA) and substantia nigra (5 cases of PD) from neuropathologically confirmed cases of disease $(200 \mathrm{mg} / \mathrm{ml})$ and injected $2.5 \mu \mathrm{l}$ into the hippocampus and $2.5 \mu \mathrm{l}$ into the overlying cerebral cortex of heterozygous M83 mice transgenic for human mutant A53T $\alpha$-synuclein. Recombinant assembled human $\alpha$-synuclein was used as a positive and cerebellar extract from a neurologically normal individual as a negative control. Upon development of hindlimb paralysis, the mice were culled, their brains and spinal cords dissected and stained for pS129 $\alpha$-synuclein, as well as Campbell-Switzer and Gallyas silver. Mice without hindlimb paralysis were culled at 18 months of age.

Thirty heterozygous M83 mice were injected with cerebellar extract from 7 cases of MSA. All injected mice developed hindlimb paralysis with an average incubation time of $167 \pm 17$ days (Table 1; Fig. 1). Assembled $\alpha$ synuclein was detected in the central nervous system (Figs. 4 and 5), with amounts and distributions similar to those previously described for homozygous M83 mice [16]. We injected 17 heterozygous M83 mice with

Table 2 Motor impairment of heterozygous mice transgenic for human mutant A53T a-synuclein following intracerebral injection of brain extracts from Parkinson's disease (PD)

\begin{tabular}{|c|c|c|c|c|c|c|c|}
\hline Human brain extract & Age at death & Mice injected & $\begin{array}{l}\text { Mice with } \\
\text { motor impairment }\end{array}$ & Survival (days) & SD & Survivors to $18 \mathrm{Mo}$ & $\begin{array}{l}\text { Survivors with } \\
\text { assembled a-synclein }\end{array}$ \\
\hline (1) $\mathrm{PD}$ & 76 & 3 & 0 & - & - & 3 & 2 \\
\hline (2) PD & 83 & 4 & 4 & 288 & 79 & - & - \\
\hline (3) PD & 92 & 3 & 1 & 265 & - & 2 & 1 \\
\hline (4) PD & 68 & 3 & 1 & 335 & - & 2 & 1 \\
\hline (5) PD & 74 & 4 & 1 & - & - & 3 & 1 \\
\hline
\end{tabular}


a

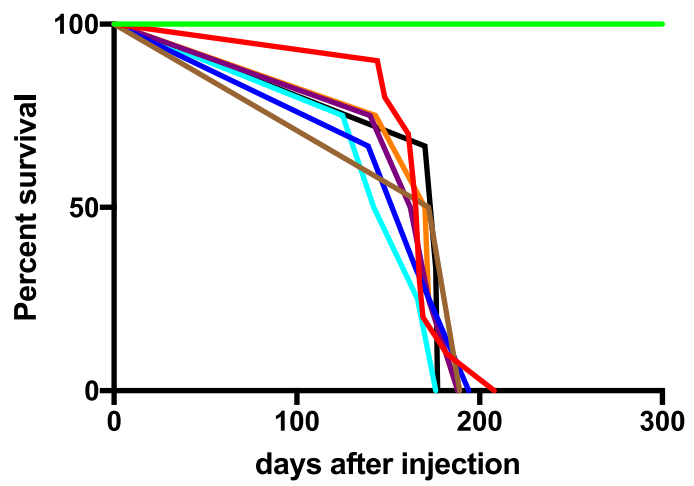

- Control Cerebellum ( $n=4)$

- (1) MSA-P cerebellum $(n=10)$

- (2) MSA-P cerebellum $(n=2)$

- (3) MSA-P cerebellum $(n=3)$

- (4) MSA-P cerebellum $(n=4)$

- (5) MSA-P cerebellum $(n=4)$

- (6) MSA-C cerebellum $(n=3)$

- (7) MSA-C cerebellum $(n=4)$

b

days after injection

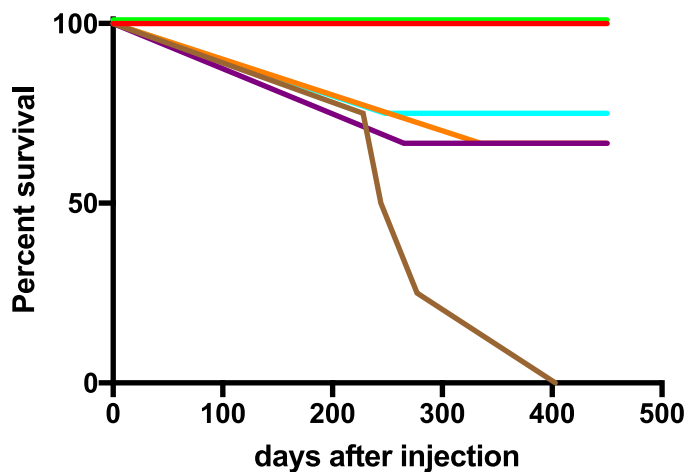

- Control Cerebellum $(n=4)$

- (1) PD substantia nigra $(n=3)$

- (2) PD substantia nigra $(n=4)$

- (3) PD substantia nigra $(n=3)$

- (4) PD substantia nigra $(n=3)$

- (5) PD substantia nigra $(n=4)$

C

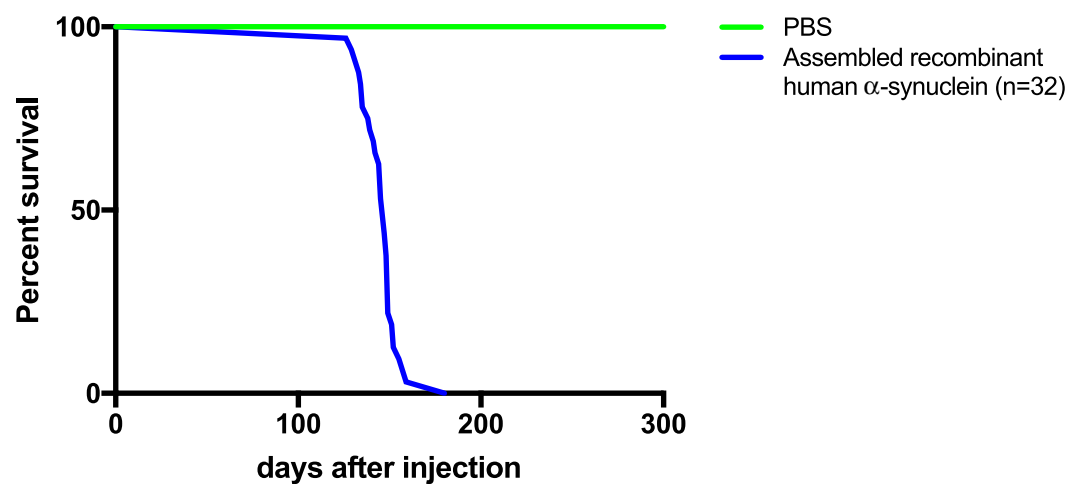

Fig. 1 Survival of heterozygous mice transgenic for human mutant A53T a-synuclein following intracerebral injection of (a) cerebellar extracts from seven patients with multiple system atrophy (MSA) and (b) substantia nigra extracts from five patients with Parkinson's disease (PD). Cerebellum from a neurologically unaffected individual served as control. Five MSA cases were of the parkinsonian type (MSA-P) and two cases of the cerebellar type (MSA-C). Assembled recombinant human a-synuclein was also injected (c)

substantia nigra extract from 5 cases of PD. Only 7 mice developed hindlimb paralysis, with an average incubation time of $286 \pm 62$ days (Table 2; Fig. 1). Assembled $\alpha$ synuclein was detected in the central nervous system, with a distribution similar to that seen in homozygous mice (Figs. 4 and 5). However, the number of inclusions was approximately two-fold less. The remaining 10 mice were culled at 18 months of age. Five mice showed staining for $\alpha$-synuclein phosphorylated at S129, with a similar distribution of pathology to that described in homozygous M83 mice, but significantly fewer inclusions in a given region. As a positive control, 32 heterozygous M83 mice were injected with $30 \mu \mathrm{g}$ assembled recombinant human $\alpha$ synuclein. All mice developed hindlimb paralysis and extensive pS129- $\alpha$-synuclein immunoreactivity, with an average incubation time of $145 \pm 10$ days (Figs. 1, 4 and 5). 


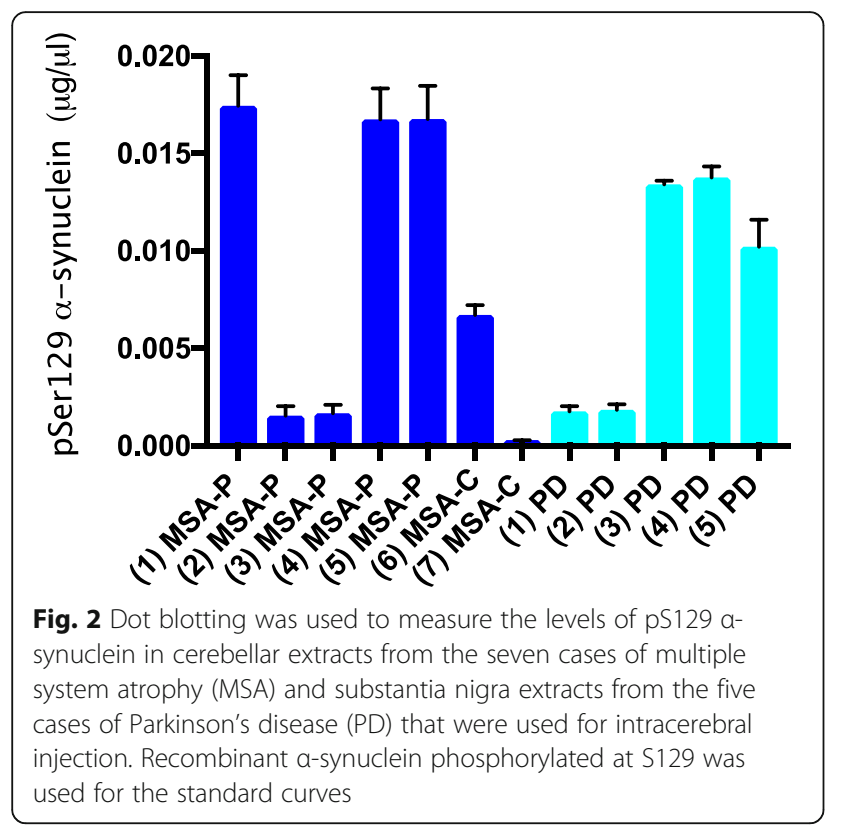

As a negative control, cerebellar extract from a 64 year old neurologically normal individual was injected into 4 heterozygous M83 mice. At 18 months of age, there were no motor symptoms or staining for $\mathrm{pS} 129 \alpha$-synuclein. Dot blotting showed that the levels of $\alpha$-synuclein phosphorylated at S129 varied between cases (Fig. 2). Thus, approximately $1 \mathrm{ng}$ assembled $\alpha$-synuclein from MSA case 7 had a similar effect as approximately $85 \mathrm{ng}$ from MSA case 1 . However, this was unlikely to account for the differences between MSA and PD. The levels of assembled $\alpha$-synuclein of MSA cases 2 and 3 were similar to those of PD cases 1 and 2.

$\alpha$-Synuclein pathologies of PD and MSA can be distinguished by silver staining [49]. PD pathology is stained by Campbell-Switzer, but not Gallyas silver. By contrast, MSA pathology is stained by both CampbellSwitzer and Gallyas silver. We confirmed these findings (Table 3; Fig. 3). Cases of PD were positive for Campbell-Switzer, but not Gallyas, whereas all cases of MSA were positive for both silver stains. Like PD, brain and spinal cord from homozygous M83 mice were positive for Campbell-Switzer, but negative for Gallyas silver (Table 3; Fig. 3). Tissue sections from heterozygous M83 mice were silver-negative.

Intracerebral injection of brain extracts from all cases of MSA and most cases of PD, as well as injection of assembled recombinant human $\alpha$-synuclein, into heterozygous M83 mice resulted in staining for pS129- $\alpha$ synuclein and motor dysfunction, leading to hindlimb paralysis (Figs. 1, 4 and 5). $\alpha$-Synuclein inclusions were stained with Campbell-Switzer silver, but not Gallyas silver, irrespective of the injected material (Table 4; Fig. 6).
Table 3 Silver staining of brain sections from multiple system atrophy (MSA) and Parkinson's disease (PD) patients. Cerebellum was used for MSA cases 2, 3, 6, 7, brainstem for cases 4, 5 and basal ganglia for case 1. Substantia nigra was used for PD cases $1,3,4,5$ and cingulate cortex for case 2

\begin{tabular}{lll}
\hline Human tissue & Gallyas silver & Campbell-Switzer silver \\
\hline (1) MSA-P & + & + \\
(2) MSA-P & + & + \\
(3) MSA-P & + & + \\
(4) MSA-P & + & + \\
(5) MSA-P & + & + \\
(6) MSA-C & + & + \\
(7) MSA-C & + & + \\
(1) PD & - & + \\
(2) PD & - & + \\
(3) PD & - & + \\
(4) PD & - & + \\
(5) PD & - & +
\end{tabular}

\section{Discussion}

Intracerebral injection of cerebellar homogenates from 7 cases of MSA into heterozygous mice transgenic for human mutant A53T $\alpha$-synuclein caused the formation of abundant neuronal $\alpha$-synuclein inclusions and severe motor dysfunction. Most cases of MSA can be divided into MSA-P, a parkinsonian variant, and MSA-C, a cerebellar variant, based on the predominant motor symptoms $[17,29]$. We injected brain extracts from 5 cases of MSA-P and 2 cases of MSA-C and did not observe any differences between cases. Future studies will have to look at additional cases of MSA-P and MSA-C. The time between injection and death was $167 \pm 17$ days. These findings confirm previous studies of MSA brain extract injections into the same mouse line [40,52].

Unlike the earlier studies, which failed to observe a motor phenotype following intracerebral injection of PD homogenates [40], we observed neuronal $\alpha-$ synuclein inclusions and hindlimb paralysis in 7 of 17 mice injected with substantia nigra extracts from $5 \mathrm{PD}$ patients. The time between injection and death was $286 \pm 62$ days. Five additional mice showed some $\alpha$ synuclein inclusions, but no motor impairment at 18 months of age. Five mice failed to develop either inclusions or motor dysfunction. These results indicate that $\alpha$-synuclein assembly preceded neurodegeneration. They are in agreement with previous studies showing that $\alpha$-synuclein inclusions from PD and DLB brains exhibit prion-like behaviour $[28,41]$.

MSA homogenates were more potent than PD homogenates, consistent with the view that $\alpha$-synuclein assemblies from MSA and PD are made of different conformers $[38,40,52]$. Negative stain electron microscopy 


\section{Campbell-Switzer}

\section{Gallyas}
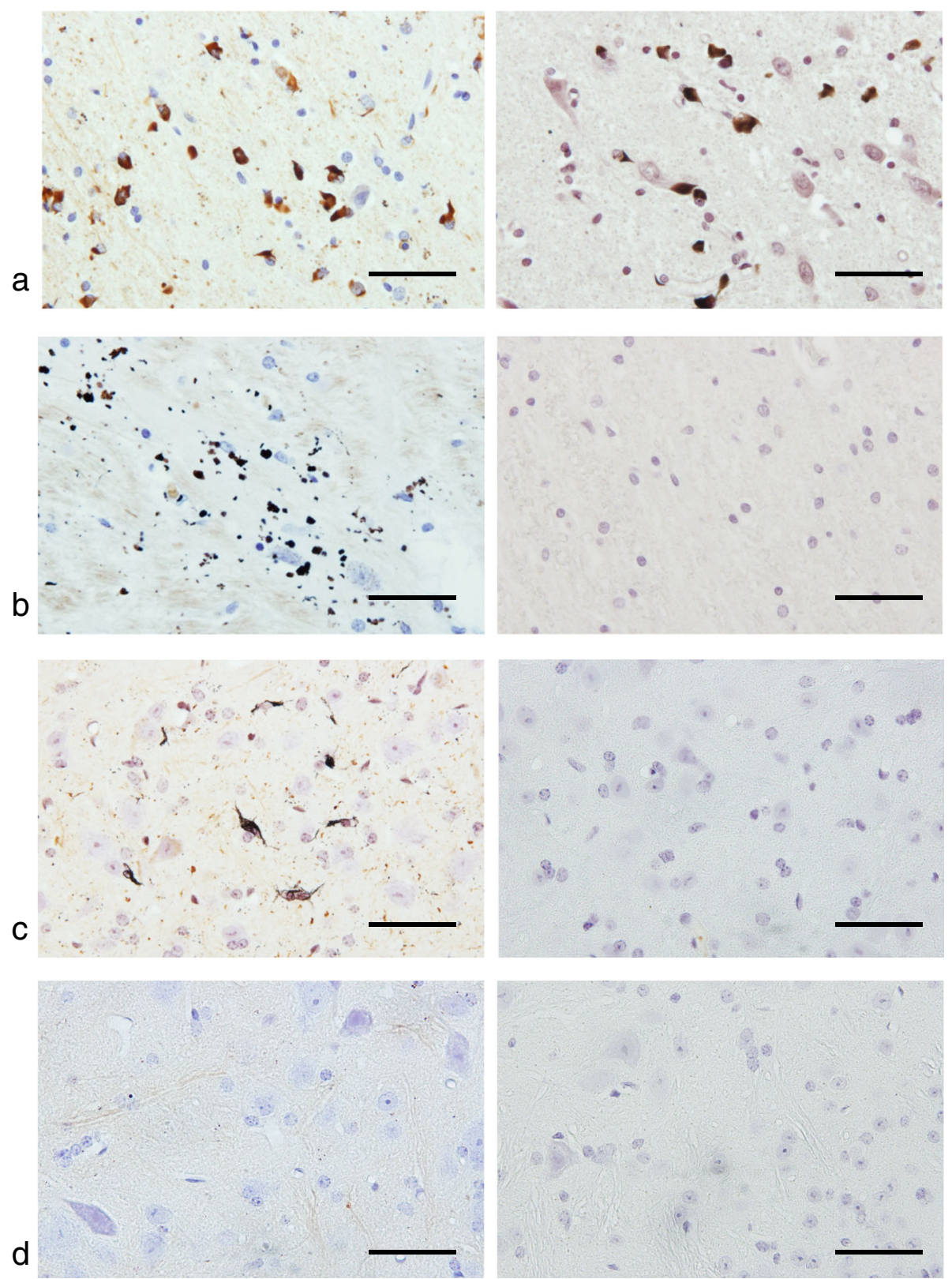

Fig. 3 Silver staining (Campbell-Switzer and Gallyas) of tissue sections from (a) brainstem of multiple system atrophy (MSA-P) case 4, (b) substantia nigra of Parkinson's disease (PD) case 5 and lumbar spinal cord of non-injected (c) homozygous (tgM83 ${ }^{+/+}$) and (d) heterozygous $\left(\operatorname{tgM} 83^{+-}\right.$) mice transgenic for human mutant A53T a-synuclein. Only MSA sections were Gallyas-positive. They were also stained by CampbellSwitzer, as were PD and tgM83 ${ }^{+/+}$sections. TgM83 ${ }^{+/-}$sections were silver-negative. Scale bars, $50 \mu \mathrm{m}$

established differences between $\alpha$-synuclein filaments of DLB, MSA and PD [7, 43, 44, 46]. Previous work using recombinant $\alpha$-synuclein showed that it can assemble into distinct filament conformations that exert differing effects [3, 37]. The structures of recombinant human $\alpha$-synuclein assembled under various conditions also showed differences [20, 25, 48]. We do not know how the structures of our recombinant $\alpha$-synuclein assemblies related to those reported by others [20,25]. Structures of $\alpha$-synuclein filaments from human brain are not known. It therefore remains to be seen how they relate to those of assembled recombinant protein. The structures of 

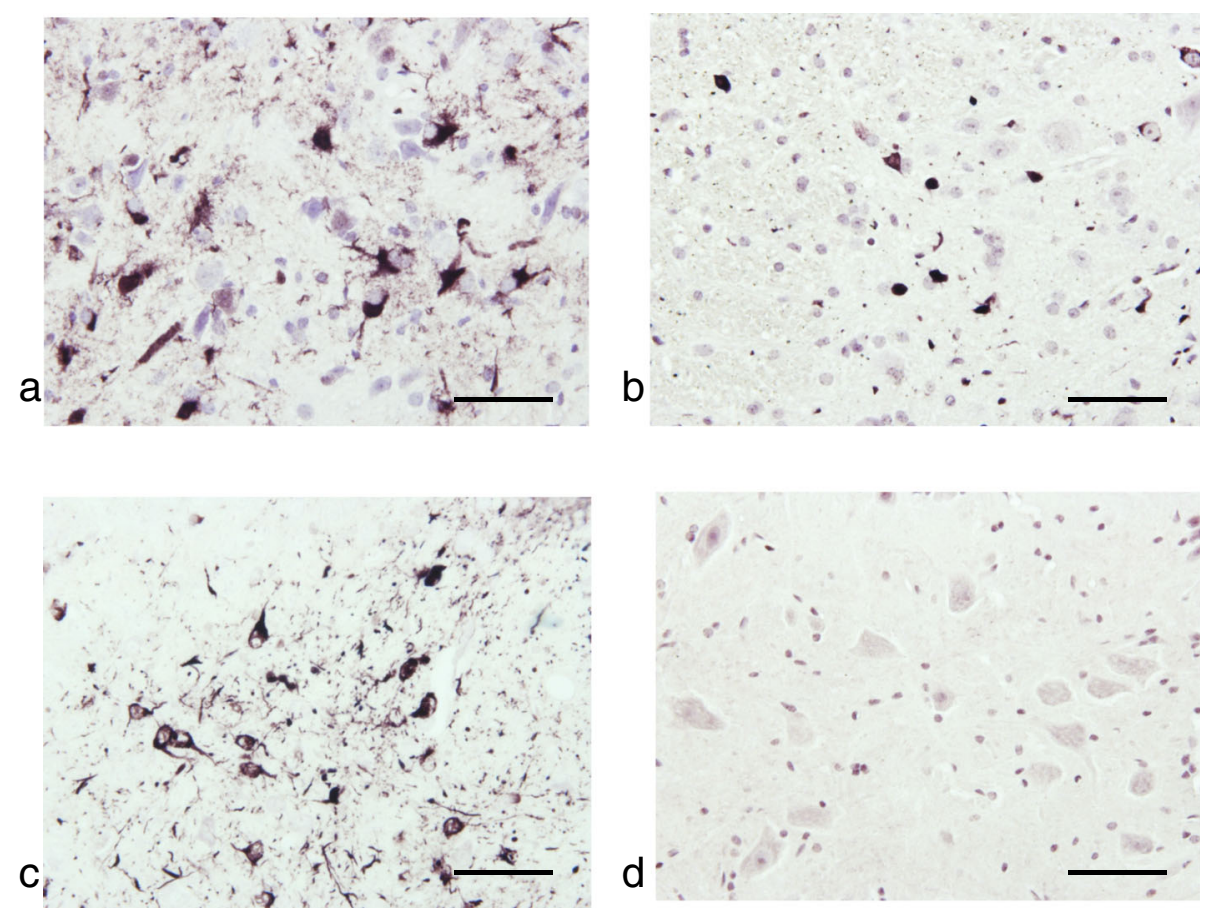

Fig. 4 Immunohistochemistry for pS129-a-synuclein of lumbar spinal cord from heterozygous mice transgenic for human mutant A53T asynuclein that were injected with (a) cerebellar extract from multiple system atrophy (MSA-P) case 1, (b) substantia nigra extract from Parkinson's disease (PD) case 3 and (c) assembled recombinant human a-synuclein. (d) Spinal cord from a non-injected mouse was used as control. Scale bars, $50 \mu \mathrm{m}$
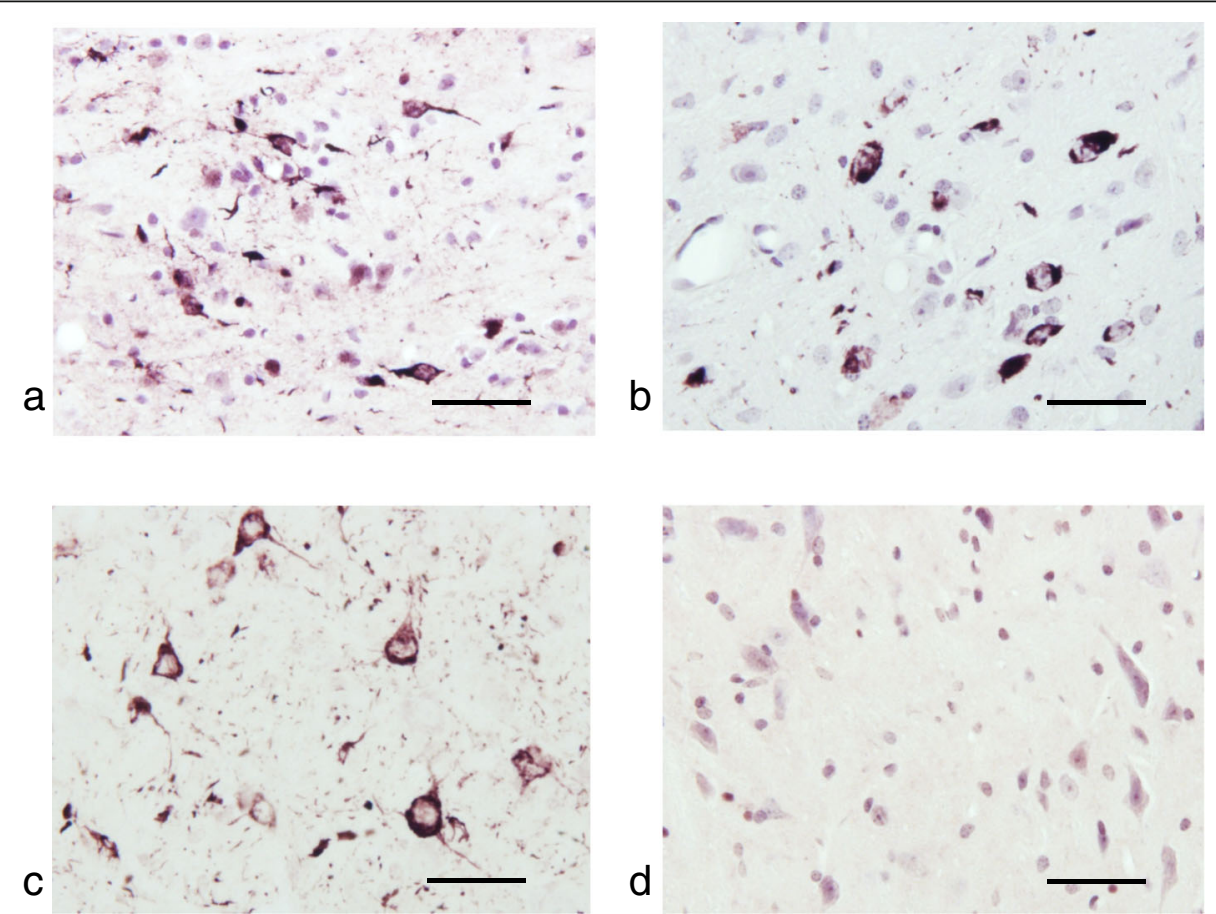

Fig. 5 Immunohistochemistry for pS129-a-synuclein of midbrain from heterozygous mice transgenic for human mutant A53T a-synuclein that were injected with (a) cerebellar extract from multiple system atrophy (MSA-P) case 1, (b) substantia nigra extract from Parkinson's disease (PD) case 3 and (c) assembled recombinant human a-synuclein. (d) Midbrain from a non-injected mouse was used as control. Scale bars, $50 \mu \mathrm{m}$ 
Table 4 Silver staining of sections from the central nervous system of heterozygous mice transgenic for human mutant A53T asynuclein $\left(\operatorname{tg} \mathrm{M} 3^{+/-}\right.$) following intracerebral injection of cerebellar homogenates from cases of multiple system atrophy (MSA) and substantia nigra homogenates from cases of Parkinson's disease (PD). Sagittal brain sections encompassed brainstem, hippocampus and cerebral cortex. Spinal cord sections were of the lumbar region

\begin{tabular}{|c|c|c|c|}
\hline Mouse & Human brain extract & Gallyas silver & Campbell-Switzer silver \\
\hline $\operatorname{tg} M 83+/+$ & - & - & + \\
\hline $\operatorname{tgM} 83+/-$ & - & - & - \\
\hline $\operatorname{tgM} 83+/-$ & (1) MSA-P & - & + \\
\hline $\operatorname{tg} M 83+/-$ & (2) MSA-P & - & + \\
\hline $\operatorname{tgM} 83+/-$ & (3) MSA-P & - & + \\
\hline $\operatorname{tgM} 83+/-$ & (4) MSA-P & - & + \\
\hline $\operatorname{tgM} 83+/-$ & (5) MSA-P & - & + \\
\hline $\operatorname{tgM} 83+/-$ & (6) MSA-C & - & + \\
\hline $\operatorname{tgM} 83+/-$ & (7) MSA-C & - & + \\
\hline $\operatorname{tgM} 83+/-$ & (1) $\mathrm{PD}$ & - & + \\
\hline $\operatorname{tg} M 83+/-$ & (2) $\mathrm{PD}$ & - & + \\
\hline $\operatorname{tgM} 83+/-$ & (3) $\mathrm{PD}$ & - & + \\
\hline $\operatorname{tg} M 83+/-$ & (4) PD & - & + \\
\hline $\operatorname{tgM} 83+/-$ & (5) PD & - & + \\
\hline
\end{tabular}

3R tau filaments from Pick's disease are different from those formed by incubating recombinant 2N3R tau with heparin $[10,54]$.

We quantified the amount of assembled $\alpha$-synuclein in brain homogenates using dot blotting and an antibody specific for pS129- $\alpha$-synuclein. Even though it has been reported that GCI- $\alpha$-synuclein is less phosphorylated at S129 than Lewy body $\alpha$-synuclein [38], the varying amounts of phosphorylated protein were unlikely to account for the differences in motor dysfunction that we observed between MSA and PD. Injection of as little as $1 \mathrm{ng}$ assembled pS129-reactive $\alpha$-synuclein was sufficient to cause motor dysfunction in heterozygous M83 mice 5 months later. However, this value may have been an underestimate, since some seed-competent species of assembled $\alpha$-synuclein may not be phosphorylated at S129 [14].

Although the filamentous inclusions of PD and MSA are made of assembled $\alpha$-synuclein, they can be distinguished by silver staining. Both types of inclusion stain with Campbell-Switzer, but only GCIs are also Gallyaspositive. This difference may reflect the presence of distinct conformers of assembled $\alpha$-synuclein. It is reminiscent of tau filaments from Alzheimer's disease, which are Campbell-Switzer and Gallyas-positive and those from Pick's disease, which are only CampbellSwitzer-positive [50]. Electron cryo-microscopy has shown that these filaments are made of different conformers of assembled tau [10, 12].

Upon intracerebral injection of MSA and PD brain homogenates into heterozygous mice transgenic for human mutant A53T $\alpha$-synuclein, inclusions were Campbell-Switzer-positive, but Gallyas-negative, like those in homozygous mice. A recent study has also shown that the inclusions formed following intracerebral injection of MSA brain extracts were Gallyasnegative [9]. Injection of assembled recombinant human $\alpha$-synuclein gave rise to Campbell-Switzer-positive, Gallyas-negative $\alpha$-synuclein inclusions. Cerebellar extract from a neurologically normal individual was without effect. These findings differ from those obtained following the injection of brain extract from APP/PS1 into APP23 transgenic mice, when the seeds determined the properties of the seeded aggregates [22].

$\alpha$-Synuclein seeds from MSA and PD brains were from end-stage disease. The mechanisms resulting in seed formation at the beginning of the pathological process are unknown. This is particularly relevant for MSA, which is defined by the presence of abundant GCIs, despite the fact that $\alpha$-synuclein is expressed at best at only low levels in oligodendrocytes and that assembly is concentration-dependent $[2,30] . \alpha$-Synuclein may give rise to a seed in as little as a single oligodendrocyte. Seeded aggregation could then proceed, even though oligodendrocytes express only low levels of $\alpha$-synuclein. Assemblies have been shown to spread between oligodendrocytes [38]. The reason why GCIs were not observed following intracerebral injection of MSA brain extracts may have been due to the lack of significant transgene expression in oligodendrocytes. It remains to be seen if the $\mathrm{A}$ to $\mathrm{T}$ mutation at residue 53 of human $\alpha$-synuclein also played a role. It will be interesting to 


\section{Campbell-Switzer}

\section{Gallyas}
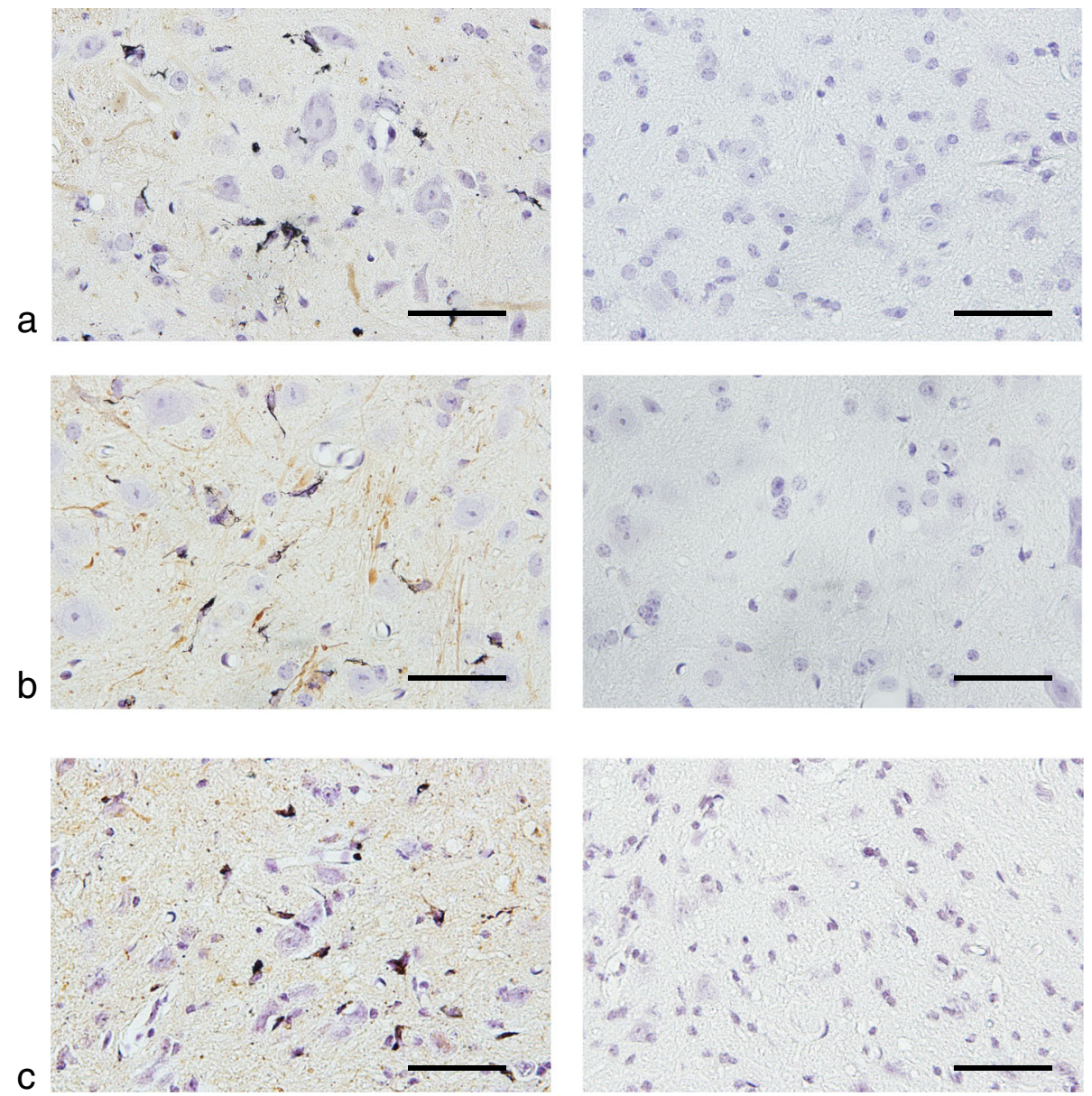

Fig. 6 Silver staining (Campbell-Switzer and Gallyas) of lumbar spinal cord from heterozygous mice transgenic for human mutant A53T asynuclein that were injected with (a) cerebellar extract from multiple system atrophy (MSA-P) case 1, (b) substantia nigra extract from Parkinson's disease (PD) case 3 and (c) assembled recombinant human a-synuclein. Scale bars, 50 um

determine the silver staining properties of the neuronal and oligodendroglial $\alpha$-synuclein inclusions that have been described in cases of PD and DLB caused by mutations in SNCA [21, 24, 27, 36].

In conclusion, the present findings show that the silver staining properties of assembled $\alpha$-synuclein in nerve cells following intracerebral injection of PD and MSA brain homogenates depend on both transgene expression and its cellular environment.

\section{Acknowledgements}

We thank the patients' families for donating brain tissue. M.G. is an Honorary Professor in the Department of Clinical Neurosciences of the University of Cambridge. J.L.H. is supported by the Multiple System Atrophy Trust, the Multiple System Atrophy Collection, Fund Sophia and CBD Solutions. B.G. is supported by NIA grant PHS P30 AG01033. M.G. is supported by the UK Medical Research Council (MC_U105184291). The Queen Square Brain Bank is supported by the Reta Lila Weston Institute for Neurological Studies and the UK Medical Research Council.

\section{Authors' contributions}

IL and MG designed experiments and drafted the manuscript. IL did intracerebral injections and analyses (immunohistochemistry and siver. staining). DP performed dot blotting and quantification of a-synuclein assemblies. MMS expressed, purified, phosphorylated and assembled recombinant human a-synuclein. AC assisted with tissue collection and animal husbandry. $J \mathrm{LH}$ and BG provided human brain tissues. All authors read and approved the final manuscript.

\section{Competing interests}

The authors declare that they have no competing interests.

\section{Author details}

${ }^{1}$ MRC Laboratory of Molecular Biology, Cambridge CB2 OQH, UK. ${ }^{2}$ Queen Square Institute of Neurology, University College, London WC1N 1PJ, UK. ${ }^{3}$ Department of Pathology and Laboratory Medicine, Indiana University School of Medicine, Indianapolis, IN 46202, USA. 
Received: 8 August 2019 Accepted: 5 September 2019 Published online: 16 September 2019

\section{References}

1. Anderson JP, Walker DE, Goldstein JM, de Laat R, Banducci K, Caccavello RJ, Barbour R, Huang J, Kling K, Lee M, Diep L, Keim PS, Shen X, Chataway T, Schlossmacher MG, Seubert P, Schenk D, Sinha S, Gai WP, Chilcote TJ (2006) Phosphorylation of Ser-129 is the dominant pathological modification of asynuclein in familial and sporadic Lewy body disease. J Biol Chem 281: 29739-29752

2. Asi YT, Simpson JE, Heath PR, Wharton SB, Lees AJ, Revesz T, Houlden H, Holton JC (2014) Alpha-synuclein mRNA expression in oligodendrocytes in MSA. Glia 62:964-970

3. Bousset L, Pieri L, Ruiz-Arlandis G, Gath J, Jensen PH, Habenstein B, Madiona K, Olieric V, Böckmann A, Meier BH, Melki R (2013) Structural and functional characterization of two alpha-synuclein strains. Nat Commun 4:2575

4. Braak E, Braak H (1999) Silver staining method for demonstrating Lewy bodies in Parkinson's disease and argyrophilic oligodendrocytes in multiple system atrophy. J Neurosci Meth 87:111-115

5. Campbell SK, Switzer RC, Martin TL (1987) Alzheimer's plaques and tangles: a controlled and enhanced silver staining method. Soc Neurosci Abstr 13:67

6. Clavaquera F, Bolmont T, Crowther RA, Abramowski D, Frank S, Probst A Fraser G, Stalder AK, Beibel M, Staufenbiel M, Jucker M, Goedert M, Tolnay M (2009) Transmission and spreading of tauopathy in transgenic mouse brain. Nat Cell Biol 11:909-913

7. Crowther RA, Daniel SE, Goedert M (2000) Characterisation of isolated asynuclein filaments from substantia nigra of Parkinson's disease brain. Neurosci Lett 292:128-130

8. Cykowski MD, Coon EA, Powell SZ, Jenkins SM, Benarroch EE, Low PA, Schmeichel AM, Parisi JE (2015) Expanding the spectrum of neuronal pathology in multiple system atrophy. Brain 138:2293-2309

9. Dhillon JKS, Trejo-Lopez JA, Riffe C, Levites Y, Sacino AN, Borchelt DR, Yachnis AY, Giasson BI (2019) Comparative analyses of the in vivo induction and transmission of a-synuclein pathology in transgenic mice by MSA brain lysate and recombinant a-synuclein fibrils. Acta Neuropathol Commun 7:80

10. Falcon B, Zhang W, Murzin AG, Murshudov G, Garringer HJ, Vidal R, Crowther RA, Ghetti B, Scheres SHW, Goedert M (2018) Structures of filaments from Pick's disease reveal a novel tau protein fold. Nature 561:137-140

11. Fanciulli A, Wenning GK (2015) Multiple system atrophy. N Engl J Med 373: 249-263

12. Fitzpatrick AWP, Falcon B, He S, Murzin AG, Murshudov G, Garringer HJ, Crowther RA, Ghetti B, Goedert M, Scheres SHW (2017) Cryo-EM structures of tau filaments from Alzheimer's disease. Nature 547:185-190

13. Fujiwara H, Hasegawa M, Dohmae N, Kawashima A, Masliah E, Goldberg MS, Shen J, Takio K, Iwatsubo T (2002) Alpha-synuclein is phosphorylated in synucleinopathy lesions. Nat Cell Biol 4:160-164

14. Gai WP, Power JHT, Blumbergs PC, Culvenor JG, Jensen PH (1999) aSynuclein immunoisolation of glial inclusions from multiple system atrophy brain tissue reveals multiprotein components. J Neurochem 73:2093-2100

15. Gallyas F (1971) Silver staining of Alzheimer's neurofibrillary changes by means of physical development. Acta Morphol Acad Scient Hung 19:1-8

16. Giasson BI, Duda JE, Quinn SM, Zhang B, Trojanowski JQ, Lee VMY (2002) Neuronal a-synucleinopathy with severe movement disorder in mice expressing A53T human a-synuclein. Neuron 34:521-533

17. Gilman S, Wenning GK, Low PA, Brooks DJ, Mathias CJ, Trojanowski JQ, Wood NW, Colosimo C, Dürr A, Fowler CJ, Kaufmann H, Klockgether T, Lees AS, Poewe W, Quinn N, Revesz T, Robertson D, Sandroni P, Seppi K, Vidailhet M (2008) Second consensus statement on the diagnosis of multiple system atrophy. Neurology 71:670-676

18. Goedert M, Jakes R, Spillantini MG (2017) The Synucleinopathies: twenty years on. J Park Dis 7:S51-S69

19. Greffard S, Verny M, Bonnet AM, Seilhean D, Hauw JJ, Duyckaerts C (2010) A stable proportion of Lewy body bearing neurons in the substantia nigra suggests a model in which the Lewy body causes neuronal death. Neurobiol Aging 31:99-103

20. Guerrero-Ferreira R, Taylor NMI, Mona D, Ringler P, Lauer ME, Riek R, Britschgi M, Stahlberg H (2018) Cryo-EM structure of alpha-synuclein fibrils. eLife 7:e36402

21. Gwinn-Hardy K, Mehta ND, Farrer M, Maraganore D, Muenter M, Yen SH, Hardy J, Dickson DW (2000) Distinctive neuropathology revealed by a- synuclein antibodies in hereditary parkinsonism and dementia linked to chromosome 4p. Acta Neuropathol 99:663-672

22. Heilbronner G, Eisele YS, Langer F, Kaeser SA, Novotny R, Nagarathinam A, Aslund A, Hammarström P, Nilsson KPR, Jucker M (2013) Seeded strain-like transmission of a-amyloid morphotypes in APP transgenic mice. EMBO Rep 14:1017-1022

23. Jakes R, Spillantini MG, Goedert M (1994) Identification of two distinct synucleins from human brain. FEBS Lett 345:27-32

24. Kiely AP, Asi YT, Kara E, Limousin P, Ling H, Lewis P, Proukakis C, Quinn N, Lees AJ, Hardy J, Revesz T, Houlden H, Holton JL (2013) a-Synucleinopathy associated with G51D SNCA mutation: a link between Parkinson's disease and multiple system atrophy? Acta Neuropathol 125:753-769

25. Li B, Ge P, Murray KA, Sheth P, Zhang M, Nair G, Sawaya MR, Shin WS, Boyer DR, Ye S, Eisenberg DS, Zhou ZH, Jiang $L$ (2018) Cryo-EM of full-length asynuclein reveals fibril polymorphs with a common structural kernel. Nat Commun 9:3609

26. Luk KC, Kehm V, Carroll J, Zhang B, O'Brien P, Trojanowski JQ, Lee VMY (2012) Pathological a-synuclein transmission initiates Parkinson-like neurodegeneration in nontransgenic mice. Science 338:949-953

27. Markopoulou K, Dickson DW, McComb RD, Wszolek ZK, Katechalidou L, Avery L, Stansbury MS, Chase BA (2008) Clinical, neuropathological and genotypic variability in SNCA A53T familial Parkinson's disease. Acta Neuropathol 116:25-35

28. Masuda-Suzukake M, Nonaka T, Hosokawa M, Oikawa T, Arai T, Akiyama H, Mann DM, Hasegawa M (2013) Prion-like spreading of pathological asynuclein in brain. Brain 136:1128-1138

29. Miki Y, Foti SC, Asi YT, Tsushima E, Quinn N, Ling H, Holton JC (2019) Improving diagnostic accuracy of multiple system atrophy: a clinicopathological study. Brain 142:2813-2827

30. Miller DW, Johnson JM, Solano SM, Hollingsworth ZR, Standaert DG, Young $A B$ (2005) Absence of a-synuclein mRNA expression in normal and multiple system atrophy oligodendroglia. J Neural Transm 112:1613-1624

31. Mougenot AL, Nicot S, Bencsik A, Morignat E, Verchère J, Lakhdar L, Legastelois S, Baron T (2012) Prion-like acceleration of a synucleinopathy in a transgenic mouse model. Neurobiol Aging 33:2225-2228

32. Nalls MA, Pankratz N, Lill CM, Do CB, Hernandez DG, Saad M, DeStefano AL, Kara E, Bras J, Sharma M, Schulte C, Keller MF, Arepalli S, Letson C, Edsall C, Stefansson $\mathrm{H}$, Liu X, Pliner $\mathrm{H}$, Lee JH, Cheng $\mathrm{R}$, Ikram MA, loannidis JP, Hadjigeorgiou JM, Bis JC, Martinez M, Perlmutter JS, Goate A, Marder K, Fiske B, Sutherland M, Xiromerisiou G, Myers RH, Clark LN, Stefansson K, Hardy JA, Heutink P, Chen H, Wood NW, Houlden H, Payami H, Brice A, Scott WK, Gasser T, Bertram L, Eriksson N, Foroud T, Singleton AB (2014) Large-scale meta-analysis of genome-wide association data identifies six new risk loci for Parkinson's disease. Nat Genet 46:989-993

33. Osterberg VR, Spinelli KJ, Weston LJ, Luk KC, Woltjer RL, Unni VK (2015) Progressive aggregation of alpha-synuclein and selective neurodegeneration of Lewy inclusion-bearing neurons in a mouse model of parkinsonism. Cell Rep 10:1252-1260

34. Papp Ml, Kahn JE, Lantos PL (1989) Glial cytoplasmic inclusions in the CNS of patients with multiple system atrophy (striatonigral degeneration, olivopontocerebellar atrophy and shy-Drager syndrome). J Neurol Sci 94:79-100

35. Papp MI, Lantos PL (1992) Accumulation of tubular structures in oligodendroglial and neuronal cells as the basic alteration in multiple system atrophy. J Neurol Sci 107:172-182

36. Pasanen P, Myllykangas L, Siitonen M, Raunio A, Kaakkola S, Lyytinen J, Tienari PJ, Pöyhönen M, Paetau A (2014) A novel a-synuclein mutation A53E associated with atypical multiple system atrophy and Parkinson's diseasetype pathology. Neurobiol aging 35:2180.e1-2180.e5

37. Peelaerts W, Bousset L, Van der Perren A, Moskalyuk A, Pulizzi R, Giugliano M, van den Haute C, Melki R, Baekelandt V (2015) a-Synuclein strains cause distinct synucleinopathies after local and systemic administration. Nature 522:340-344

38. Peng C, Gathagan RJ, Covell DJ, Medellin C, Stieber A, Robinson JL, Zhang B, Pitkin RM, Olufemi MF, Luk KC, Trojanowski JQ, Lee VMY (2018) Cellular milieu imparts distinct pathological a-synuclein strains in asynucleinopathies. Nature 557:558-563

39. Polymeropoulos MH, Lavedan C, Leroy E, Ide SE, Dehejia A, Dutra A, Pike B, Root H, Rubenstein J, Boyer R, Stenroos ES, Chandrasekharappa S, Athanassiadou A, Papapetropoulos T, Johnson WG, Lazzarini AM, Duvoisin RC, Di lorio G, Golbe LI, Nussbaum RL (1997) Mutation in the alphasynuclein gene identified in families with Parkinson's disease. Science 276: 2045-2047 
40. Prusiner SB, Woerman AL, Mordes DA, Watts JC, Rampersaud R, Berry DB, Patel S, Oehler A, Lowe JK, Kravitz SN, Geschwind DH, Glidden DV, Halliday GM, Middleton LT, Gentleman SM, Grinberg LT, Giles K (2015) Evidence for a-synuclein prions causing multiple system atrophy in humans with parkinsonism. Proc Natl Acad Sci U S A 112:E5308-E5317

41. Recasens A, Dehay B, Bové J, Carballo-Carbajal I, Dovero S, Pérez-Villalba AM, Fernagut PO, Blesa J, Parent A, Perier C, Farinas I, Obeso JA, Bezard E, Vila M (2014) Lewy body extracts from Parkinson disease brains trigger a-synuclein pathology and neurodegeneration in mice and monkeys. Ann Neurol 75: 351-362

42. Sasakawa H, Sakata E, Yamaguchi Y, Masuda M, Mori T, Kurimoto E, Iquchiu T, Hisanaga SI, Iwatsubo T, Hasegawa M, Kato K (2007) Ultra-high field NMR studies of antibody binding and site-specific phosphorylation of asynuclein. Biochem Biophys Res Commun 363:795-799

43. Spillantini MG, Crowther RA, Jakes R, Cairns NJ, Lantos PL, Goedert M (1998) Filamentous a-synuclein inclusions link multiple system atrophy with Parkinson's disease and dementia with Lewy bodies. Neurosci Lett 251:205-208

44. Spillantini MG, Crowther RA, Jakes R, Hasegawa M, Goedert M (1998) aSynuclein in filamentous inclusions of Lewy bodies from Parkinson's disease and dementia with Lewy bodies. Proc Natl Acad Sci U S A 95:6469-6473

45. Spillantini MG, Schmidt ML, Lee VMY, Trojanowski JQ, Jakes R, Goedert M (1997) a-Synuclein in Lewy bodies. Nature 388:839-840

46. Tarutani A, Arai T, Murayami S, Hisanaga SI, Hasegawa M (2018) Potent prion-like behaviors of pathogenic a-synuclein and evaluation of inactivation methods. Acta Neuropathol Commun 6:29

47. Tu PH, Galvin JE, Baba M, Giasson B, Tomita T, Leight S, Nakajo S, Iwatsubo T, Trojanowski JQ, Lee VMY (1998) Glial cytoplasmic inclusions in white matter oligodendrocytes of multiple system atrophy brains contain insoluble a-synuclein. Ann Neurol 44:415-422

48. Tuttle MD, Comellas G, Nieuwkoop AJ, Covell DJ, Berthold DA, Kloepper KD, Courtney JM, Kim JK, Barclay AM, Kendall A, Wan W, Stubbs G, Schwieters CD, VMY L, George JM, Rienstra DM (2016) Solid-state NMR structure of a pathogenic fibril of full-length human a-synuclein. Nat Struct Mol Biol 23:409-415

49. Uchihara T, Nakamura A, Mochizuki Y, Hayashi M, Orimo S, Isozaki E, Mizutani T (2005a) Silver stainings distinguish Lewy bodies and glial cytoplasmic inclusions: comparison between Gallyas-Braak and Campbell Switzer methods. Acta Neuropathol 110:255-260

50. Uchihara T, Tsuchiya K, Nakamura A, Akiyama H (2005b) Silver staining profiles distinguish pick bodies from neurofibrillary tangles of Alzheimer type: comparison between Gallyas and Campbell-Switzer methods. Acta Neuropathol 109:483-489

51. Wakabayashi K, Yoshimoto M, Tsuji S, Takahashi H (1998) a-Synuclein immunoreactivity in glial cytoplasmic inclusions in multiple system atrophy. Neurosci Lett 249:180-182

52. Watts JC, Giles K, Oehler A, Middleton L, Dexter DT, Gentleman SM, DeArmond SJ, Prusiner SB (2013) Transmission of multiple system atrophy prions to transgenic mice. Proc Natl Acad Sci U S A 110:19555-19560

53. Yoshida H, Craxton M, Jakes R, Zibaee S, Tavaré R, Fraser G, Serpell LC, Davletov B, Crowther RA, Goedert M (2006) Synuclein proteins of the pufferfish Fugu rubripes: sequences and functional characterization. Biochemistry 45:2599-2607

54. Zhang W, Falcon B, Murzin AG, Fan J, Crowther RA, Goedert M, Scheres SHW (2019) Heparin-induced tau filaments are polymorphic and differ from those of Alzheimer's and Pick's diseases. eLife 8:e43584

\section{Publisher's Note}

Springer Nature remains neutral with regard to jurisdictional claims in published maps and institutional affiliations.

Ready to submit your research? Choose BMC and benefit from:

- fast, convenient online submission

- thorough peer review by experienced researchers in your field

- rapid publication on acceptance

- support for research data, including large and complex data types

- gold Open Access which fosters wider collaboration and increased citations

- maximum visibility for your research: over $100 \mathrm{M}$ website views per year

At BMC, research is always in progress.

Learn more biomedcentral.com/submissions 